\title{
Impact of Anxiety on Academic Achievement among Engineering Students
}

\author{
Sindhu $\mathrm{P}^{1 *}$
}

\section{ABSTRACT}

The present study is aimed to find the relationship of Anxiety with Academic achievement among engineering students. The target population of the study comprised of students of few Engineering colleges under VTU (Visvesvaraya Technological University). For the study, a sample of 20 Undergraduate students of the Visvesvaraya Technological University (studying Engineering) was taken. The Beck's Anxiety Inventory was used to measure the level stress among the students. The in-depth investigation of the findings obtained through this study reveals that there exists a relation between Anxiety and Academic score of students. The findings of the study will be useful in assisting Educators, Counselors, Psychologists, and Researchers to develop strategies to enhance students’ psychological well-being.

Keywords: Anxiety, Beck, Low and High Achieving Students, University.

It is a fact that a nation's progress depends upon its students' academic achievements and development. That's why every nation emphasizes students' academic achievements. The academic achievements of the students are badly affected due to increase in anxiety in the society. There is no denying to the fact that anxiety has increased in the society it not only affects education but also students’ personalities which linger throughout their lives.

Teachers' guidance tracks the attitudes, goals, aspirations and values of students towards the right direction. Some people believe that anxiety is most often present as a self-protection mechanism that surfaces in response to threatening situations.

In behavioural terms Sarason (1980) defined anxiety as a conditioned response to a perceived threatening stimulus which could be learned or inherited. In a similar way, May (1977) viewed anxiety as a maladjusted behaviour. Benjamin (1987 .p.78) noted that anxiety can interface with attention, learning and testing. The idea that anxiety may interface with a student's ability to demonstrate what they have learned is not new. Anxiety can also interface with learning in that

\footnotetext{
${ }^{1}$ Department of Psychology, Bharathiar University, Coimbatore, India *Responding Author

(C) 2016 Sindhu P; licensee IJIP. This is an Open Access Research distributed under the terms of the Creative Commons Attribution License (http://creativecommons.org/licenses/by/2.0), which permits unrestricted use, distribution, and reproduction in any Medium, provided the original work is properly cited.
} 
anxious students are more easily distracted by irrelevant or incidental aspects of the task at hand, having trouble in focusing on significant details.

Some people view the behaviour of anxious students who perceive the classroom experience to be threatening perhaps because of history and expectation of failure or because they anticipate negative consequences if they attempt to achieve. Some research has reported that highly anxious students often indulge in daydreaming. These behaviours make us think about ways of protecting ourselves from a perceived threat but each interface with our productivity and achievements. The relationship between anxiety and academic achievements is complex. Although high levels of anxiety may approve performance on simple well practiced task, yet it seems to interface with academic performance on new or difficult assignments. In general anxiety that is too high can block learning and teachers with high anxious students may need to concentrate on building relationship that allow the students to feel not threatened in that environment. Anxiety has been linked to poor academic performance. High levels of academic anxiety can negatively affect working memory (Owens, Stevenson, Hadwin, \& Norgate, 2012).

\section{LITERATURE REVIEW}

Anxiety is a psychological disorder that is associated with significant suffering and impairment in functioning. It is a blend of thoughts and feelings characterized by a sense of uncontrollability and unpredictability over potentially aversive life events (Wilson, Nathan, O’leary, \& Clark, 1996).

The relationship between anxiety and academic performance has been studied in a variety of laboratory and natural settings. Individuals experiencing anxiety show apprehensions that often interfere with performance in everyday life as well as in academic situations. Anxiety in general is expected to have a negative effect on performance.

One consistent finding shows that individuals who have a high level of anxiety perform less well than those who have low anxiety on evaluative or ego-threatening tasks (Vogel \& Collins, 2000). In a study conducted by Anson et al. (1984) on the relationship between anxiety and academic performance, it was found that anxiety was significantly and negatively correlated with grades obtained by the students.

The way students perceive and experience their academic-related matters is also one of the factors that could affect the performance of the students. For instance, according to Vogel and Collins (2000), if an individual's experience of previous achievement is negative, then the anxiety level is higher and this leads to lower performance. Consequently, if the experience is positive, then the anxiety level is lower and this leads to a higher performance. Overall, it is important to consider motives, aptitudes, cognitive assessments of the task, and past experience when analyzing anxiety and examining how it relates to performance.

(c) The International Journal of Indian Psychology, ISSN 2348-5396 (e) | ISSN: 2349-3429 (p) | 101 
Andrews and Wilding (2004) found that 40\% of a cohort of University College, London students had attended the student health clinic for psychological problems, characterised by anxiety, tension and poor concentration. Compared with the norm, the cohort as a whole also had elevated neuroticism scores. Their distress levels were found to be associated with low academic performance.

Another study on anxiety was conducted by Seligmen and Wuyek (2007). They found that highly-anxious students were significantly more likely to score lower on measures of academic achievement and peer acceptance. Longitudinal analyses revealed that highly-anxious students, compared to their less-anxious peers, scored significantly lower on measures of academic achievement, aggression, and peer acceptance.

Mokashi (2007) studied the correlates of anxiety and scholastic achievement of residential school students and found no significant relationship between ordinal position, type of family, family size, income of the family, arts and music, sports, intelligence and scholastic achievement of the boys. Age was negatively related with the scholastic achievement of the boys. No significant relationship was found between age, ordinal position, type of family, family size and income of the family and scholastic achievement of girls. Arts and music, sports and intelligence were positively related to scholastic achievement of the girls.

Yousefi, et al. (2010) conducted a study on the relationship between test-anxiety and academic achievement among Iranian adolescents and found that there is a significant correlation between test anxiety and academic achievement among adolescents. Previous literature review concludes that adolescents suffer from one or more psychological problems during this period. Some problems are identifiable and transient whereas others are not (Chhabra and Sodhi 2011).

All the above studies showed that anxiety can directly influence students' academic achievement. It was reported that anxiety could effect students' academic achievement in the sense that students with high anxiety level perform poorer compared to those with low anxiety.

\section{Objective of the Study}

- The objective of the study is to find the relationship of Anxiety with the academic achievements of students.

\section{Hypothesis}

The following hypotheses are formulated and tested:

The Null Hypotheses is as follows:

1. There is no effect of Anxiety on Academic achievement.

2. The alternative hypotheses are as follows:

3. There is significant effect of Anxiety on Academic achievement.

(c) The International Journal of Indian Psychology, ISSN 2348-5396 (e)| ISSN: 2349-3429 (p) | 102 


\section{RESEARCH METHODOLOGY}

The sample of this study consisted of 20 Engineering students of the VTU University, out of which 15 were considerable. They were selected using random sampling technique. For the purpose of the study, the participants were divided into two groups, low and high achieving groups. Low achieving group refers to students who obtained percentage below 60\%, and high achieving group refers to students who obtained percentage of $60 \%$ and above. The study used Beck’s Anxiety Inventory questionnaire to gather information regarding levels of anxiety.

\section{TESTING OF HYPOTHESIS}

Descriptive statistics used in this quantitative research work were percentages, means, and standard deviations. For the analysis, Independent sample t-tests were used to measure differences between low and high achieving groups in their depression levels. The hypothesis has been formulated as the initial step. A test statistic must be defined to test the validity of the hypothesis.

The test statistic is computed from sample information. Here, t- test is chosen as statistical test and a standard value of Significance level (0.05). A decision rule is used to accept or reject the null hypothesis.

Two types of analyses were performed to identify the differences in stress level between high and low achieving students. First, the means and standard deviations were obtained to determine the extent to which these two groups reported experiencing depression. Second, t-tests were conducted to evaluate whether the differences in levels of depression between low and high were significant or not. The result of the same has been tabulated as shown below.

Table 1: Mean, Standard Deviation, T-test and p values of Measurements

\begin{tabular}{|l|l|l|l|l|l|l|l|l|}
\hline & \multicolumn{3}{|c|}{$\begin{array}{c}\text { Low Achieving Students } \\
\text { (3) }\end{array}$} & \multicolumn{2}{c|}{$\begin{array}{c}\text { High Achieving Students } \\
\text { (12) }\end{array}$} & \multicolumn{2}{c|}{$\begin{array}{c}\text { Level of } \\
\text { Significance }= \\
\text { 0.05 }\end{array}$} \\
\hline Measurements & Mean & SD & DF & Mean & SD & DF & t Test & $\begin{array}{l}\text { P } \\
\text { Value }\end{array}$ \\
\hline Anxiety & 27.33 & 15.95 & 2 & 15.75 & 8.88 & 11 & 1.74 & 0.05 \\
\hline
\end{tabular}

(c) The International Journal of Indian Psychology, ISSN 2348-5396 (e)| ISSN: 2349-3429 (p) | 103 
Figure 2: Relationship between Anxiety and Academic Performance

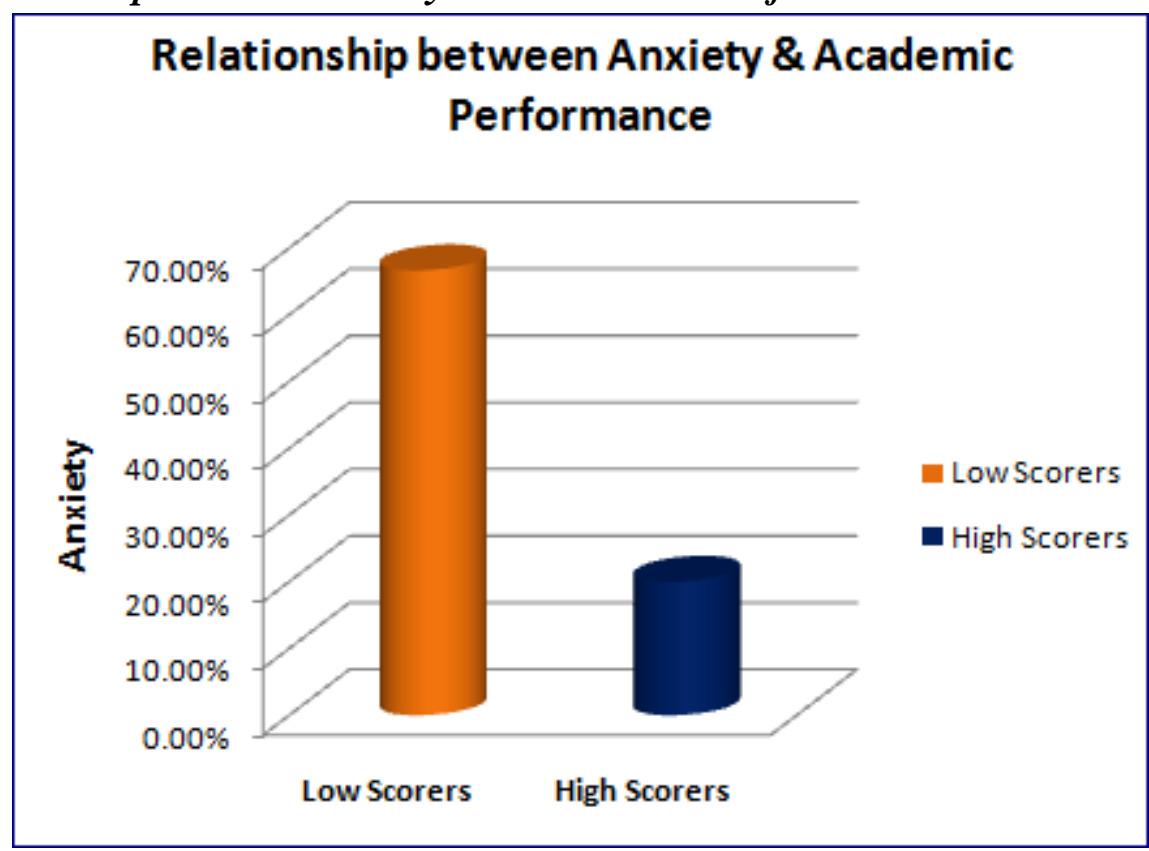

Descriptive analysis also shows that the mean score for Anxiety of low achieving students was 27.33 (SD = 15.95) and the mean score for high achieving students was 15.75 (SD = 8.88). Independent sample t-test yielded a significant difference in Anxiety between the low-and highachieving group, $\mathrm{t}(15)=1.74$. Since $\mathrm{p}<=0.05$, the null hypothesis is rejected. In other words, there is effect of Anxiety on student's academic performance. The results of the test showed that almost $67 \%$ of low scorers showed high anxiety and only $20 \%$ of high scorers showed high anxiety. This result indicates that low achievers have higher level of anxiety compared to high scorers (See Figure 2).

\section{DISCUSSION}

The present study was conducted to examine the effect of anxiety between low-and highachieving students. 20 undergraduate students, both males and females, were selected as participants in this study. By having knowledge and understanding on this research study, it could help many, such as educators, counselors, and psychologist to design and develop proper intervention program to reduce psychological problems among students. The students themselves could benefit from the study. Information and ideas gained from this research could help them to face, manage, and handle the psychological problems. Therefore, enhancing knowledge and strategies in controlling psychological problems among students may help to increase their academic achievement.

\section{CONCLUSION}

The present generation engineering students faces more Anxiety. In an attempt to understand the relationship between anxiety and academic performance, the anxiety level of students is

(c) The International Journal of Indian Psychology, ISSN 2348-5396 (e)| ISSN: 2349-3429 (p) | 104 


\section{Impact of Anxiety on Academic Achievement among Engineering Students}

measured. Specifically, students are divided into low-achieving group and high-achieving groups and their anxiety level is compared. The findings of the present study indicated that low scorers reported higher level of anxiety compared to high scorers. This finding of the study can help to design programmes and strategies to boost students’ performance in academic life.

\section{Acknowledgments}

The author appreciates all those who participated in the study and helped to facilitate the research process.

\section{Conflict of Interests}

The author declared no conflict of interests.

\section{REFERENCES}

A Study on Academic Anxiety among Adolescents of Minicoy Island by Bhutnath Mahato1, Sunil Jangir2, in International Journal of Science and Research (IJSR), India Online ISSN: 2319-7064.

Anxiety, Optimism and Academic Achievement among Students of Private Medical and Engineering Colleges: A Comparative Study by Indoo Singh1 \& Ajeya Jha1, in Journal of Educational and Developmental Psychology; Vol. 3, No. 1; 2013 ISSN 1927-0526 EISSN 1927-0534, Published by Canadian Center of Science and Education.

Baloglu, M. (2003). Individual differences in statistics anxiety among college students. Personality and Individual Differences, 34, 855-865.http://dx.doi.org/10.1016/S0191 8869(02)00076-4

Bryme B (2000) Relationship between Anxiety, Fear, Self Esteem and Coping Strategies. Journal of Educational psychology. Vol 35(137): 201-215.

Differences in Psychological Problems between Low and High Achieving Students by Md Aris Safree Md Yasin 1 andMariam Adawiah Dzulkifli 2, The Journal of Behavioral Science 2009. Vol.4 No.1. 49-58.

Ibrahim A R (1997) Changes in Levels of Anxiety of College Students. Journal of education. Vol 16(11).

Laurence, B. Williams, C. and Eiland, D. (2009) The Prevalence and Socio-demographic Correlations of Depression, Anxiety, and Stress among a group of university students. Journal of American Health. 58.94-105.

Prima Vitasari, Muhammad Nubli Abdul Whab, Ahmad Othman, Tutut Herwan, Suriya Kumar Sinndurai, "The Relationship between Study Anxiety and Academic Performance among Engineering Students” Procedia - Social and Behavioral SciencesVolume 8, 2010, Pages 490-497.

Psychological factors affecting student's academic performance in higher education among students, by Riya Bhattacharya 1 , Dr. Bani Bhattacharya 2 INTERNATIONAL 
Impact of Anxiety on Academic Achievement among Engineering Students

JOURNAL FOR RESEARCH \& DEVELOPMENT IN TECHNOLOGY, Volume4,Issue-1, July- 2015, ISSN (O) :- 2349-3585.

Research in Humanities, Arts and Social Sciences ISSN (Print): 2328-3734, ISSN (Online): 2328-3696, ISSN (CD-ROM): 2328-3688.

Singh A K \& Gupta A S(1986) academic anxiety Scale for Children. Agra. Nationa Psychological Corporation.

The Effects of Anxiety on Achievement and Performance: A College Study by Dr. Naveed Shibli, Naila Nawaz, Nazima Ameen ,Sehrish Fatima, Hafiza Sadia Khan, Qurat ul Ain, in International Journal of Scientific and Research Publications, Volume 5, Issue 6, June 2015, ISSN 2250-3153.

The Impact of Anxiety on Academic Achievement of U.G. Students by Dr. Shailendra Singh, in American International Journal of

Yousefi F, Talib M A, Mansor B M, Juhari B R and Redzuan R(2010) Test Anxiety and Academic Achievement among Iranain Adolescents. Journal of asian social Science. Vol 6(5).

How to cite this article: Sindhu P (2016), Impact of Anxiety on Academic Achievement among Engineering Students, International Journal of Indian Psychology, Volume 4, Issue 1, No. 80, ISSN:2348-5396 (e), ISSN:2349-3429 (p), DIP:18.01.111/20160401, ISBN:978-1-365-57867-0

(c) The International Journal of Indian Psychology, ISSN 2348-5396 (e)| ISSN: 2349-3429 (p) | 106 